$\begin{array}{ll}\text { Abstracta Iranica } & \begin{array}{l}\text { Abstracta Iranica } \\ \text { Revue bibliographique pour le domaine irano-aryen }\end{array} \\ & \text { Volume } \mathbf{2 8} \mid \mathbf{2 0 0 7} \\ & \text { Comptes rendus des publications de } \mathbf{2 0 0 5}\end{array}$

\title{
Psychology of Early Sufi Sama: Listening and altered states. London, Routledge Curzon, 2004, $250 \mathrm{p}$.
}

Ève Feuillebois-Piérunek

\section{OpenEdition Journals}

Édition électronique

URL : http://journals.openedition.org/abstractairanica/12732

DOI : 10.4000/abstractairanica. 12732

ISSN : 1961-960X

Éditeur :

CNRS (UMR 7528 Mondes iraniens et indiens), Éditions de l'IFRI

Édition imprimée

Date de publication : 15 mai 2007

ISSN : 0240-8910

Référence électronique

Ėve Feuillebois-Piérunek, «Psychology of Early Sufi Sama: Listening and altered states. London, Routledge Curzon, 2004, 250 p. », Abstracta Iranica [En ligne], Volume 28 | 2007, document 274, mis en ligne le 18 septembre 2007, consulté le 25 septembre 2020. URL : http://journals.openedition.org/ abstractairanica/12732 ; DOI : https://doi.org/10.4000/abstractairanica.12732

Ce document a été généré automatiquement le 25 septembre 2020

Tous droits réservés 


\title{
Psychology of Early Sufi Sama: Listening and altered states. London, Routledge Curzon, 2004, $250 \mathrm{p}$.
}

\author{
Ève Feuillebois-Piérunek
}

1 L'A. étudie la psychologie des états de conscience modifiés chez les premiers soufis, ainsi que le $s a m \bar{a}^{c}$ et son utilisation pour induire ce type d'expérience, à partir de textes de la tradition mystique musulmane du Xe au XII ${ }^{\mathrm{e}}$ siècle.

2 Après une introduction générale (chap. 1), il se penche sur la présentation du sama $\bar{a}^{c}$ dans la littérature soufie primitive (chap. 2), puis étudie le vocabulaire technique relatif à cette pratique (sama $\bar{a}^{\prime}, h \bar{a} l$, vaqt, qalb), principalement à partir des écrits de Sarrāj, Sullamī, Qošayrī, Abū Ḥāmed Ġazzālī, Hojvīrī et 'Ațțār (chap. 3). Les deux chapitres suivants (4 et 5) sont consacrés à la psychologie du sama $\bar{a}^{c}$ : Avery y analyse de nombreux récits d'expériences et de comportements mystiques, charismes de guérison, manifestations physiques incontrôlées, paroles extatiques, cris et larmes ou joie exubérante, perte de sensibilité, folie, mort subite. Les chapitres 6 et 7 relatent les explications données par les soufis eux-mêmes de ces différents phénomènes. Le chapitre 8 présente l'étiquette et les rites du concert spirituel. Un ouvrage complet et intéressant.

INDEX

Thèmes : 8 . Soufisme 
AUTEURS

ÈVE FEUILLEBOIS-PIÉRUNEK

Sorbonne Nouvelle - Paris III 